\title{
先天股脱の治療中に起こる大腿骨頭の変化について
}

\begin{tabular}{cccc}
\multicolumn{2}{l}{ 県立宮崎病院整形外科 } & & \\
岩 & 切 & 清 & 文 \\
甲 & 斐 & & 佐 \\
姫 & 野 & 忠 & 彦
\end{tabular}

\section{The Changes Occurring in the Femoral head of Cougenital Dislocation of the Hip}

By

\author{
K. Iwakiri, T. Kai \& T. Himeno \\ Department of Orthopedic Surgery, Miyazaki \\ Prefectural Hospital
}

\begin{abstract}
The material consisted of 298 cases (428hips). In this series 140 hips had no changes and other hips had presented various changes.

These changes were classified in atrophy, partial defect, irregular margin, cloudy figure, condensation, and overlapping of the head on the metaphysis, and each of them were examined according to the reduced age, grade of dislocation and the method of treatment.

The earliest change is the atrophy and this change becomes to normal figure or varies to other changes. In these various changes, condensation, fragmentation and overlapping figure are presented relatively in late stadium and their late results are worse than the other changes.
\end{abstract}

先天性股関節脱曰日治療成績に大きな影響を及ぼす ものの一つとして大腿骨頭の変形があげられており， 吾々が先天股脱治療経過中に各種の骨頭核の変化に遭 遇しているととは事実である. 此の骨頭核の変化の代 表的なものとして従来ペルテス椂変化という表現で, 諸家の報告がなされているが, 吾々は先天股脱治療中 亿起乙る大腿骨頭の変化を，骨頭核の萎縮，部分欠 損, 辺縁不整, 雲䋈状変化, 濃縮扁平化, 分裂, 骨頭 核と顓部メタフィーゼの重複の七ツの変化に分類し, その出現頻度を整復時年令, 脱曰度, 治療法別に調查 し, 更に整復から変化の出現までの期間, 変化の出現 から恢復が始まるまでの期間, 各变化の他の変化への 移行率, 及び, 各変化の予後について調查したので, その結果を報告する.

1. 症例は昭和 34 年より昭和 45 年初頭までに当科 を受診した 298 例， 424 関節である. 治療は開排のみ で整復されるものと,リーメンビューゲル法を用いた まの以外は, 原則として率引後全身麻酔下に徒手整復
し, 大部分は $2 \sim 3$ 週間のギプス固定後, デニスブラ ウン型装具か, 合成樹脂製硬性装具に通算約 4 ケ月固 定し, 以後徐々に自動運動を許可している（表1）.

2. 骨頭核発現時期：浜田, 深堀等の報告では夫久 3〜8 ケ月，5ケ月とされているが，吾々の健側にお ける骨頭核の出現は 2 ケ月〜10ケ月平均 5.6 ケ月であ った。患側骨頭核の出現は，脱臼度が高度となるにし たがい出現月数は遅延している. 更に治療開始後骨頭 核が出現するまでの月数も脱臼度に比例して遅延して いる(表 2).

3.骨頭核に変化が認められず，全過程を順調に経 過したものは全症例の約 $1 / 3$ 亿相当する 100 例 140 股 であるが，幼児期に治療をはじめられたものと脱曰度 の軽度なうのに多く，固定法では関節運動が許容され るものに変化が起とらないととが示されており,リー メンビューゲル法の優秀性があらわれている（表 3 ).

4. 骨頭核の変化について

(1) 骨頭核の萎縮（86 股）：此の変化は高年令で整 
1 調查症例 昭和 34 年 昭和 45 年

298 例 424 関 節

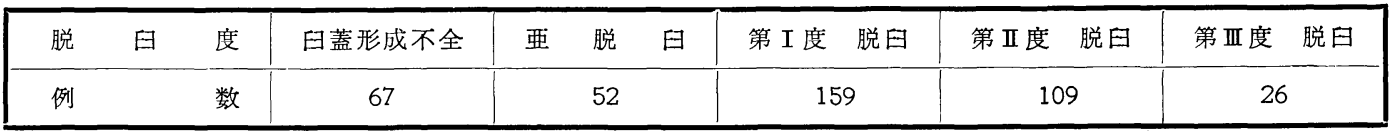

\begin{tabular}{|c|c|c|c|c|c|}
\hline 治療開始時年令 & 3 ケ月末満 & 3 ケ月〜 6 ケ月 & 6ケ月〜 才 & $1 \sim 2$ 才 & 2 才以上 \\
\hline 例 & 95 & 115 & 64 & 112 & 38 \\
\hline
\end{tabular}

\begin{tabular}{|c|c|c|c|c|c|c|c|}
\hline 主な治療法 & オムツカバー & Riemen-Bügel & Denis-Browne & 硬性装具 & ギ & $フ^{\circ} \pi$ & 観血的整復 \\
\hline 数 & 13 & 68 & 69 & 105 & & 15 & 11 \\
\hline
\end{tabular}

表 2 骨頭 核出現時期 (平均月数)

\begin{tabular}{|c|c|c|c|c|c|c|c|c|}
\hline 期 間 & 健 & 側 & 臼蓋形成不全 & & 脱 日 & 第 I 度脱日 & 第 II 度脱日 & 第 III度脱臼 \\
\hline $\begin{array}{l}\text { 生 後 } \\
\text { 治療開始後 }\end{array}$ & & & $\begin{array}{l}5.1 \\
2.9\end{array}$ & & $\begin{array}{l}6.5 \\
3.1\end{array}$ & $\begin{array}{l}7.6 \\
3.7\end{array}$ & $\begin{array}{r}14.9 \\
4.3\end{array}$ & - \\
\hline
\end{tabular}

表 3 骨頭核変化を起さなかったもの（100例 140関節）

\begin{tabular}{|c|c|c|c|c|c|c|}
\hline 治療開始時年令 & 3 ケ月未満 & 3 ケ月〜 6 ケ月 & 6 ケ月〜 1 才 & 1 才〜 2 才 & 2 才以上 & \multirow{4}{*}{$\begin{array}{l}\text { 注）表 } 1 \text { の各 } \\
\text { 例数ごとの } \\
\text { 無変化の割 } \\
\text { 合を示す }\end{array}$} \\
\hline 頻 度 (\%) & 67.4 & 41.7 & 25.0 & 10.7 & \multirow{2}{*}{ 第吕度脱臼 } & \\
\hline 脱 $⿴$ 度 & 日蓋形成不全 & 亜 脱 日 & 第 I 度脱臼 & 第 II 度脱 & & \\
\hline 頻 度 (\%) & 65.7 & 50.0 & 42.1 & 6.4 & 0 & \\
\hline 主な治療法 & オムツカバー & Riemen-Bügel & Denis-Browne & 硬性装具 & ギ プ ス & 観血的整復 \\
\hline 頻 度 (\%) & 92.3 & 73.2 & 24.2 & 18.1 & 6.7 & 9.1 \\
\hline
\end{tabular}

復された高度脱四例に起こり易く, 特に関節運動が強 く制限されるギプス治療のみのものに多発している.

(2) 辺縁不整（75 股）: 生後 $1 \sim 2$ 年の間に整復さ れたものに多く見られ，第 2 度脱巨に多く，硬性装 具, デニスブラウン装具, 観血整復の間に殆えど差が 見られない.リーメンビューゲル法でも $11.8 \%$ 亿認 められている.

(3) 部分欠損 (79 股)：6 ケ月〜 2 才の間に比較的 多く見られるが，2才以上のものに少ないのは興味が ある．脱曰度では第 2 度に多く，固定法ではデニスブ ラウン装具, ギプス固定に多発しているが, リーメン ビューゲル法にも $13.2 \%$ に認められている.

(4) 雲絮状変化（39股）: 各年令層, 脱巨度共に出 現頻度は低く，2才以上のものと第 3 度脱臼では出現 していない，治療法では観血整復後の骨頭に多発して
いる.

(5) 濃縮扁平化 (90 股)：高年令, 高度脱曰のもの に多く, リーメンビューゲル法以外の治療法のすべて に頻発している.

(6) 骨頭核の分裂（53 股）: 各年令層脱曰度共にあ まり高率ではないが，観血整復例の $3 / 1$ 強に出現して いる. 分裂の形態には二様のものがあるが，その経過 については後述する。

(7) 骨頭核と頸部メタフィーゼの重複 (59 股)：骨 頭核认起てる変化のうちでは最も重篤で予後不良とさ れるものであるが，3 ケ月以下，2才以上のものに発 現が少なく，その中間の年令㬝に集中している．脱臼 度では第 2 度脱臼に多く, 治療法ではリーメンビュー ゲル法で $1.5 \%$ で極めて少ないのが注目される（表 4 ). 
表 4 骨頭核変化の種障と詳細

\begin{tabular}{|c|c|c|c|c|c|c|c|c|c|}
\hline \multirow{2}{*}{$\begin{array}{l}\text { 骨頭核変化 } \\
\text { の 種 類 }\end{array}$} & \multicolumn{3}{|c|}{ 治 療 開 始 洔 年 令 別 } & \multicolumn{3}{|l|}{ 脱 $⿴$} & \multicolumn{3}{|l|}{ 治 } \\
\hline & 令 & 変化例 & $\%$ & 脱 $⿴ \zh11$ 度 & 変化例 & $\%$ & 治 療 法 & 変化例 & de \\
\hline $\begin{array}{l}\text { 萎 縮 } \\
\text { (86関節) }\end{array}$ & $\begin{array}{l}3 \text { ケ月末満 } \\
3 \sim 6 \text { 月 } \\
6 \sim 13 \text { ケ } \\
1 \sim 2 \text { 才 } \\
2 \sim \text { 才以 } \\
\text { 不 }\end{array}$ & $\begin{array}{r}4 \\
9 \\
6 \\
37 \\
26 \\
4\end{array}$ & $\begin{array}{r}4.2 \\
7.8 \\
9.4 \\
33.0 \\
68.2 \\
-\end{array}$ & 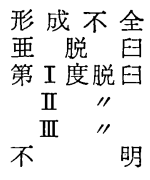 & $\begin{array}{r}2 \\
4 \\
22 \\
38 \\
21 \\
0\end{array}$ & $\begin{array}{r}3.0 \\
7.7 \\
13.8 \\
34.7 \\
80.8 \\
-\end{array}$ & $\begin{array}{l}\text { オムツカバー } \\
\text { R. B. 装 具 } \\
\text { D. B. } \\
\text { 硬 性” } \\
\text { ギ } \\
\text { 観 血 整 復 }\end{array}$ & $\begin{array}{r}0 \\
5 \\
17 \\
39 \\
11 \\
5\end{array}$ & $\begin{array}{r}0 \\
7.3 \\
24.2 \\
38.1 \\
73.3 \\
45.6\end{array}$ \\
\hline $\begin{array}{l}\text { 辺縁不整 } \\
\text { (75関節) }\end{array}$ & $\begin{array}{l}3 \text { ケ月未満 } \\
3 \sim 6 \text { 月 } \\
6 \sim 12 \text { ケ } \\
1 \sim 2 \text { 才 } \\
2 \sim \text { 才以 } \\
\text { 不 }\end{array}$ & $\begin{array}{r}7 \\
7 \\
13 \\
34 \\
41 \\
0\end{array}$ & $\begin{array}{r}7.4 \\
6.1 \\
20.3 \\
30.4 \\
10.5 \\
-\end{array}$ & $\begin{array}{c}\text { 形成不全 } \\
\text { 亜 脱 } \\
\text { 第 I 度脱臼 } \\
\text { II " } \\
\text { III " }{ }^{\prime \prime}{ }^{2} \text { 明 }\end{array}$ & $\begin{array}{r}4 \\
2 \\
30 \\
35 \\
3 \\
1\end{array}$ & $\begin{array}{r}6.0 \\
3.8 \\
18.9 \\
32.1 \\
11.5 \\
-\end{array}$ & $\begin{array}{l}\text { オムッカバー } \\
\text { R. B. 装 具 } \\
\text { D. B. } \\
\text { 硬 性" } \\
\text { ギプ } \\
\text { 観 血整 復 }\end{array}$ & $\begin{array}{r}0 \\
8 \\
20 \\
31 \\
3 \\
3\end{array}$ & $\begin{array}{c}0 \\
11.8 \\
29.0 \\
29.5 \\
20.0 \\
27.3\end{array}$ \\
\hline $\begin{array}{l}\text { 部分欠損 } \\
\text { (79関節) }\end{array}$ & $\begin{array}{l}3 \text { ケ月末満 } \\
3 \sim 6 \text { 月 } \\
6 \sim 12 \text { 月 } \\
1 \sim 2 \text { 才 } \\
2 \sim \text { 才以 } \\
\frac{1}{\text { 不 }}\end{array}$ & $\begin{array}{r}5 \\
21 \\
14 \\
32 \\
5 \\
1\end{array}$ & $\begin{array}{r}5.3 \\
18.3 \\
21.9 \\
28.6 \\
13.2 \\
-\end{array}$ & 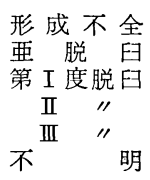 & $\begin{array}{r}4 \\
4 \\
26 \\
39 \\
5 \\
0\end{array}$ & $\begin{array}{r}6.0 \\
7.7 \\
16.4 \\
35.8 \\
19.2 \\
\end{array}$ & $\begin{array}{l}\text { オムッカバー } \\
\text { R. B. 装 具 } \\
\text { D. B. } \\
\text { 硬 性" } \\
\text { ギプ } \\
\text { 観 血 整 復 }\end{array}$ & $\begin{array}{r}0 \\
9 \\
29 \\
29 \\
5 \\
3\end{array}$ & $\begin{array}{c}0 \\
13.2 \\
42.0 \\
27.0 \\
33.3 \\
27.3\end{array}$ \\
\hline $\begin{array}{l}\text { 電 絮 状 } \\
\text { (39関節) }\end{array}$ & $\begin{array}{l}3 \text { ケ月未満 } \\
3 \sim 6 \text { 月 } \\
6 \sim 12 \text { 月 } \\
1 \sim 2 \text { 才 } \\
2 \sim \text { 才以 上 } \\
\frac{1}{\text { 不 }}\end{array}$ & $\begin{array}{r}2 \\
11 \\
9 \\
17 \\
0 \\
0\end{array}$ & $\begin{array}{c}2.1 \\
9.6 \\
14.1 \\
15.2 \\
0 \\
-\end{array}$ & 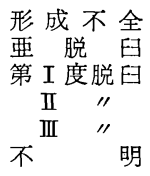 & $\begin{array}{r}0 \\
0 \\
15 \\
21 \\
0 \\
3\end{array}$ & $\begin{array}{c}0 \\
0 \\
9.4 \\
19.3 \\
0 \\
-\end{array}$ & $\begin{array}{l}\text { オムッカバー } \\
\text { R. B. 装 具 } \\
\text { D. B. B. } \\
\text { 硬 性 " } \\
\text { ギプ } \\
\text { 観 血 整 復 }\end{array}$ & $\begin{array}{r}0 \\
3 \\
14 \\
16 \\
0 \\
4\end{array}$ & $\begin{array}{c}0 \\
4.4 \\
20.3 \\
15.2 \\
0 \\
33.4\end{array}$ \\
\hline $\begin{array}{c}\text { 膿縮(扁平) } \\
\text { (90関節) }\end{array}$ & $\begin{array}{l}3 \text { ヶ月未満 } \\
3 \sim 6 \text { 月 } \\
6 \sim 12 \text { 月 } \\
1 \sim 2 \text { 才 } \\
2 \text { 才以 } \\
\text { 不 }\end{array}$ & $\begin{array}{r}8 \\
16 \\
19 \\
29 \\
18 \\
0\end{array}$ & $\begin{array}{r}8.4 \\
13.9 \\
28.7 \\
25.9 \\
47.4 \\
-\end{array}$ & $\begin{array}{c}\text { 形成不全 } \\
\text { 亜 脱 } \\
\text { 第 I 度脱臼 } \\
\text { II " } \\
\text { III }{ }^{\prime \prime}{ }^{\prime \prime} \text { 明 }\end{array}$ & $\begin{array}{r}2 \\
1 \\
27 \\
47 \\
10 \\
3\end{array}$ & $\begin{array}{r}3.0 \\
1.9 \\
17.0 \\
43.1 \\
38.5 \\
-\end{array}$ & $\begin{array}{l}\text { オムッカバー } \\
\text { R. B. 装 具 } \\
\text { D. B. B. } \\
\text { 硬 性 " } \\
\text { ギプ } \\
\text { 観血整 復 }\end{array}$ & $\begin{array}{r}0 \\
5 \\
23 \\
41 \\
5 \\
5\end{array}$ & $\begin{array}{r}0 \\
7.3 \\
33.3 \\
39.0 \\
33.3 \\
45.6\end{array}$ \\
\hline $\begin{array}{l}\text { 分 裂 } \\
\text { (53関節) }\end{array}$ & $\begin{array}{l}3 \text { ケ月末澫 } \\
3 \sim 6 \text { 月 } \\
6 \sim 12 \text { 月 } \\
1 \sim 2 \text { 才 } \\
2 \sim \text { 才以 } \\
\frac{1}{\text { 不 }}\end{array}$ & $\begin{array}{r}7 \\
13 \\
11 \\
19 \\
3 \\
0\end{array}$ & $\begin{array}{r}7.4 \\
11.3 \\
17.2 \\
17.0 \\
7.9 \\
-\end{array}$ & 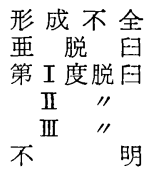 & $\begin{array}{r}3 \\
2 \\
17 \\
24 \\
2 \\
5\end{array}$ & $\begin{array}{r}4.5 \\
3.8 \\
10.7 \\
22.0 \\
7.7 \\
-\end{array}$ & $\begin{array}{l}\text { オムッカバー } \\
\text { R. B. 装 具 } \\
\text { D. B. B " } \\
\text { 硬 性 " } \\
\text { ギプ ス } \\
\text { 観 血整 復 }\end{array}$ & $\begin{array}{r}2 \\
2 \\
16 \\
21 \\
1 \\
4\end{array}$ & $\begin{array}{r}15.4 \\
2.9 \\
23.2 \\
20.0 \\
6.7 \\
36.4\end{array}$ \\
\hline $\begin{array}{l}\text { 核と頸部 } \\
\text { の重 複 } \\
\text { (59関節) }\end{array}$ & $\begin{array}{l}3 \text { ケ月末澫 } \\
3 \sim 6 \text { 月 } \\
6 \sim 12 \text { ケ } \\
1 \sim 2 \text { 才 } \\
2 \sim \text { 才以 } \\
\frac{1}{\text { 不 }}\end{array}$ & $\begin{array}{r}5 \\
14 \\
10 \\
28 \\
2 \\
0\end{array}$ & $\begin{array}{r}5.3 \\
12.2 \\
15.6 \\
25.0 \\
5.3 \\
-\end{array}$ & 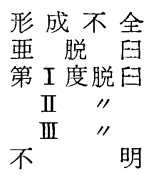 & $\begin{array}{r}0 \\
0 \\
18 \\
36 \\
1 \\
4\end{array}$ & $\begin{array}{r}0 \\
0 \\
11.3 \\
33.0 \\
3.8 \\
-\end{array}$ & $\begin{array}{l}\text { オムツカバー } \\
\text { R. B. 装 具 } \\
\text { D. B. } \\
\text { 硬 性 " } \\
\text { ギ プ } \\
\text { 観 血 整 復 }\end{array}$ & $\begin{array}{r}0 \\
1 \\
18 \\
23 \\
3 \\
3\end{array}$ & $\begin{array}{r}0 \\
1.5 \\
26.1 \\
21.9 \\
20.0 \\
27.3\end{array}$ \\
\hline
\end{tabular}

（\%は本表の変化例を表 1 の各項の対応する例数で除したもの）

\section{5. 骨頭核変化の出現時期について}

大まかに云えば，固定開始から平均 3.4 ケ月即ち， まだ固定が続けられている期間内に骨萎縮が出現する 傾向があり，4ケ月以後即ち固定から次第に運動を開 始し，患児が自ら起立するようになる時期となれば辺 縁不整, 雲婪状変化, 部分欠損等の変化に変わってく る.その後てれらの変化が互いに移行して最後に残る
変化として, 濃縮扁平化, 分裂, 核と頚部メタフィー ゼの重複が挙げられ，これらの変化は特に骨頭の形態 が完成される祭に重要な影響を及ぼすものと考えられ る (表 5 ).

6 . 骨頭核に出現した変化が恢復しはじめる時期に ついて

骨萎縮, 雲絮状変化, 部分欠損の三者は残りの四者 
表 5 骨頭核変化の予後

\begin{tabular}{|c|c|c|c|c|}
\hline 変化の種類 & $\begin{array}{l}\text { 治療開始 } \\
\text { 吸変化 } \\
\text { 出現まで } \\
\text { の月数 }\end{array}$ & \begin{tabular}{|} 
変変化出 \\
現か占恢 \\
復開始ま \\
の゙の数
\end{tabular} & $\begin{array}{c}\text { 他の変 } \\
\text { 化への } \\
\text { 移行率 } \\
\%\end{array}$ & $\begin{array}{c}\text { 正常化率 } \\
\%\end{array}$ \\
\hline $\begin{array}{l}\text { 萎 縮 } \\
\text { 整 } \\
\text { 部 分欠 損 } \\
\text { 需 絮 状 } \\
\text { 濃縮 (扁平) } \\
\text { 核 の 分裂 } \\
\text { 頸部との重複 }\end{array}$ & $\begin{array}{l}3.4 \\
6.5 \\
6.7 \\
6.6 \\
7.1 \\
7.8 \\
8.9\end{array}$ & $\begin{array}{l}4.9 \\
6.9 \\
5.5 \\
4.0 \\
6.7 \\
6.0 \\
6.3\end{array}$ & $\begin{array}{l}69.1 \\
61.9 \\
40.0 \\
68.4 \\
28.4 \\
34.1 \\
32.2\end{array}$ & $\begin{array}{r}24.7 \\
25.4 \\
33.4 \\
15.8 \\
27.0 \\
25.0 \\
8.4\end{array}$ \\
\hline
\end{tabular}

に比し恢復のはじまりが早い，即ち早期に出現した変 化は恢復しはじめるのま早い，他方遅れて出現した変 化は恢復しはに゙めるのも遅れる傾向がうかがわれる (表 5 ).

\section{7. 各変化の他の変化への移行について}

比較的早期に出現するととろの骨萎縮, 辺縁不整, 雲䋈状変化, 部分欠損のうち, 部分欠損を除いて他の 変化は半数以上が他の変化へ移行し, 遅れて出現する 濃縮, 分裂, 重複等の変化は, 他の変化への移行が少 ないととがわかる（表 5 ）.

\section{8. 最終的に正常化するものの比率}

症例のすべてが最終的な結果を見るてよができる時 点まで追跡されたわけではなく，同じ変化を残存した ままで治療を中止しているものが相当数に上っている ことは残念であるが, 正常化率の最も高いのは骨頭核 の部分欠損であった．此の変化は比較的早期に出現し 恢復のはじまりも早く，他の変化への移行も少ないの で，正常化率が最も良いという結果が見られたのは当 然の帰結と考えられる.

核の分裂するものの正常化率は $25.0 \%$ と他の大部 分の変化と類似の比率を示しているが，此の中には単 に中央部で 2 分される型のものと，分節状に分裂する ものの二つの型があり, 前者は早期に恢復して正常化 するため，乙れを除外した後者のみの比率を上れば恢 復のはじまりの平均値は更に遅れ, 正常化率は悪化す るものと考元れる。

変化の出現も恢復のはしまりも遅く, 他の変化への 移行率も少ないもののうち特に骨頭核と頸部メタフィ 一ゼの重複を起としたものの正常化率は特に悪いとい う事実は, 此の変化が骨頭の形態に最も重大な影響を 与える変化であるてとを示すものであると考える（表 5 ).

綜括：先天股脱の治療成績に関与する因子として,
骨頭変形, 曰蓋形成不全, 遺残性亜脱曰⿴三者が挙げ られる。そのうち骨頭変形の原因としては，整復時の 外傷, 骨頭の循環障害, 長期固定により骨頭に加わる 圧迫，寛骨臼と骨頭の不適合，先天因子，等を鈴木は 分類しているが，吾々の症例においては骨頭に対する 整復時の外傷は可及的に避けた積りである。しかもな お治療した骨頭のうち終了まで全く骨頭核に変化を示 さなかったものは 424 股中の 140 股（約 30\%）にす ぎず, 途中何等かの変化を起ししながら最終的に正常 化したもの103 股を加えても243 股が正常化したとい う結果しか得られていない。

斯様に多発する骨頭の变化を脱臼度, 年令治療法を 中心として追跡したのであるが，脱四度の高度のもの は比較的年長のものに多く，治療法も好結果を得た R. B. 法は本質的に機能的整復を期待する方法である ため, 脱曰度の低いものに集中する傾向があったこと は否定できない，併し R. B. 法以前に行なわれた他動 的機械的方法では骨頭核の変化の発生率は更に高度で あることは Pavlik 以来既に多くの報告がなされてい ๖.

今回の調査結果を各変化別に概括すれば，骨萎縮， 濃縮化は年長児, 高度脱曰児に出現するものが多く, 辺縁不整, 分裂, 部分欠損, 雲姀状変化等は比較的年 少者に起てり易いもののようである．年長児と年少児 とは脱臼度に差があり, 年長児の方が強度な整復操作 を受け, 整復後の固定も強度なものを必要とする可能 性が強い. しかも内転筋に代表される骨頭への纴迫力 も強いものと考えられるので，とれらの要素が骨萎 縮, 濃縮化と関連をもつかもしれない. 又 Idelberger は大腿骨の成長のために坟期間のギプス固定では骨頭 の圧迫壊死を来たすと述べているが，此の観点に立っ て治療法別に変化の発生率を見れば, 理論的には骨成 長に伴う調節が最も不自由な合成樹脂製硬性装具に最 も変化が多発し，1 ケ月毎に交換するギプスがてれに つぎ, 大腿部のみを固定するデニスブラウン型装具で は発生しない筈であるが, 調査結果では明らかに発生 率に差があると思われるのは骨萎縮のみであり, 他の 変化では著明な差は認められていない，骨萎縮がデニ スブラウン装具に比較的少ないのは或程度の可動性が 許さんるからであろうか.

更に全体的な萎縮, 濃縮と異なり, 辺縁不整分裂, 部分欠損等の部分的な変化が比較的年少者に起こり易 いというととは, 或年令を境として骨頭の強靯性に年 
長児と年少児の間に相違があるととを示すものではな からうか.

今回の調査では Incongruity と骨頭循環の影響に ついての結果を提示することができなかったが，今後 更に関節造形所見との対比及び骨頭核増大パターンを 調查し, 上記の問題を追跡する予定である.

\section{参考文献}

1）浜淳道：日整会誌 $43: 1 \sim 13,1969$.
2) Idellerger K : 日整総会講演 昭 41 .

3）光安元夫, 松尾隆: 整形外科と災害外科 20 : 226-230. 1971.

4）岡田靖：日整会誌 $44: 117-133,1970$.

5) Pavlik, A : Z. Orthop., : $89: 341 \sim 352$, 1957.

6）鈴木良平：日整会誌：43：722-724. 1969.

7）鈴木良平：先夫性股関節脱臼とその機能的療法 南江堂 昭 46 .

8）坂口亮：日整会誌 $43: 725 \sim 77,1969$.

9）横倉誠次郎：骨光 V 線䧐断指針南江堂 昭327.

\title{
一次性変形性股関節症のレ 線的分類の試み
}

\author{
北里大学医学部整形外科 \\ 有冨 \\ 寛 \\ Oxford 大学整形外科
}

John Cockin

\section{Clinical and Radiological Review on Primary Osteoarthritis of the Hip Joint}

\author{
by \\ Hiroshi Aritomi, M. D., \\ from the Department of Orthopedic surgery, \\ Kitazato University, School of Medicine. \\ John Cockin, F.R.C.S., \\ from Nuffield Department of Orthopedic \\ Surgery, University of Oxford.
}

One hundred twenty-three patients from primary osteoarthritis of the hip joint were reviewed radiologically and clinically.

Three basically different types of primary osteoarthitis were described radiologically for the cases at the advanced stage in combination with the severity index as semiquantative evaluation for deterioration of the disease.

Three different types are lateral displacement of the head or subluxation type, deformed or destructive head type, and concentric or protrusion type.

The correlation was studied between clinical observation and radiological type and severity as well.

It has been discussed on etiological factor such as anatomical, vascular, and metabolic factor in relation to aging and pressure imbalance in the hip joint.

It was suggested that treament of primary osteoarthritis, especially the operative method should be properly chosen after more accurate of clinical and radiological evaluation.

1. 緒言

一次性あるいは原発性変形性股関節症の明確なる臨
床診断基準の設定はなお困難であり, 従ってその病因 も不明である.従って現在の所, 一次性変形性股関節 症の定義は, 発熱, 貧血等の全身症状を伴なわず股関 